\title{
Biodiversity and Carbon Potentials of a Nigerian Forest Reserve: Insights from the Niger Basin
}

\author{
Nwabueze I. Igu ${ }^{*}$, Chukwudi P. Nzoiwu1, Evaristus U. Anyaeze ${ }^{2}$ \\ ${ }^{1}$ Department of Geography and Meteorology, Nnamdi Azikiwe University, Awka, Nigeria \\ ${ }^{2}$ Department of Environmental Management, Nnamdi Azikiwe University, Awka, Nigeria \\ Email: *nwabuezeigu@gmail.com
}

How to cite this paper: Igu, N.I., Nzoiwu, C.P. and Anyaeze, E.U. (2017) Biodiversity and Carbon Potentials of a Nigerian Forest Reserve: Insights from the Niger Basin. Journal of Environmental Protection, 8, 914-922. https://doi.org/10.4236/jep.2017.88057

Received: June 7, 2017

Accepted: July 17, 2017

Published: July 20, 2017

Copyright $\odot 2017$ by authors and Scientific Research Publishing Inc. This work is licensed under the Creative Commons Attribution International License (CC BY 4.0).

http://creativecommons.org/licenses/by/4.0/

\begin{abstract}
Forest reserves are expected to host a wide array of biodiversity and provide refuge for rare species that may be threatened in nearby forest landscapes. While this is the guiding protocol for most reserves across the tropics, such as Nigeria, the extent to which they host biodiversity and act as potential stores for carbon are quite uncertain. This study used a four hectare randomly selected forest plots to verify the biodiversity of the reserve, its stand structure and potentials for carbon storage. Species importance value was used to summarize the composition of the landscape. Both the diversity (mean diversity $=0.85$ ) and species richness (eleven species) were low. Biodiversity in the area was quite poor and was mostly composed of Elaeis guineensis and Gmelina arborea, which had relative densities of $74.6 \%$ and $11.96 \%$, respectively. Over exploitation and preference for fast-growing exotic species explained the poor stand structure and composition of the landscape, respectively. Very few tree stands were found in the mature structural class, and its capacity to facilitate regeneration and resilience seemed low. Its ability to store carbon in its biomass is equally low; since the forest landscape was much degraded. Maximizing the vast land of the reserve for targeted carbon storage (through mass tree planting) is a potential step that could forestall carbon sequestration across the region, especially because, such vast and available (forest) land cannot be guaranteed in most other forest landscapes.
\end{abstract}

\section{Keywords}

Conservation, Degradation, Freshwater, Management, Swamp, Tropical

\section{Introduction}

Tropical forests are host to a wide array biodiversity and important for global climatic processes. Yet its rate of forest loss and conversions are so alarming that 
up to 13 million forests are felled or razed each year across the tropics [1] [2]. Such disruption of the tropical ecosystem are thought to constitute a greater peril for global biodiversity than any other contemporary phenomenon [3] [4] [5] and poses a major threat to the vast array of services that the ecosystem provides. In a bid to address these issues and ensure that tropical biodiversity is conserved, forest reserves and protected areas were established across many tropical areas, including Africa [6] [7]. These (reserves and protected areas) were to be used to preserve the wide array of biodiversity found in the region and serve as refuge for species that are threatened in other natural landscapes (outside protected areas). Protected areas are equally seen as the only channel by which obligate forest species could be safeguarded; especially those ones that are found in the remains of ancient logs that are decaying [8]. While these facts appear to be known across many parts of the tropics, the underlying reasons for establishing reserves are not mostly realized. This has remained a challenge across many tropical areas mainly because, such landscapes are equally prone to environmental stress and human encroachment [5].

Even though Nigeria occupies a large land mass, only about 10 percent of its land area are occupied by forests [9]. Among this land area, about 445 gazetted reserves exist across the entire ecological zones found within the country [10]. With the reserves varying in size across the different ecological zones, so likewise do their timber output as well: with the savanna having lesser than what is found in the forest zones. Though several attempts have been made to increase the extents or sizes of the forest reserves across the country, it has however not yielded much result compared to the initial time (during the colonial times) when much land was easily gazetted. It seemed easier for communities or regions to part with their land then than in recent times that is characterized by higher population growth and greater demand for land.

These reserves (which are mostly extensive in size) are managed at the state levels by the different State Forestry Departments whose emphasis or target is (varied) dependent on the ecological location or peculiarities. Hence, while the ones in southern Nigeria (where most of the forests are found) are mostly particular with log harvesting, those in the northern part focus mostly on tree establishment for environmental protection, fuelwood and livestock production [11]. Even though these forest reserves have existed for many years, there is much doubt as to whether the reserves are achieving its original aim of conserving biodiversity. Understanding this trend across southern Nigeria (being where the forests are concentrated) will help to provide insights that could be used to manage the reserves more effectively. Specifically, this work aims to show how effective reserves could be as hosts of biodiversity, and furthermore, elucidate its potentials for sequestering carbon across the region.

\section{Materials and Methods}

\subsection{Study Area}

The study region is an extensive sedimentary basin that is found in the lower 
reaches of the Niger basin (Figure 1). It is a low-lying region characterized by annual flooding and resultant accumulation of mineral-rich sediments. Soils of the region are mainly delimited as hydromorphic soils and are either seasonally or permanently waterlogged [12]. The region is broadly made up of marine sedimentaries of lower and upper cretaceous age [13] and filled by a succession of thinly bedded silts and clay. Its rainy months are quite long and last mainly between March and October, while its dry season is quite short (mainly between November and February). Keay [14] classified the vegetation of the region as freshwater swamp forest. Its canopies are rather open and in gaps. Land use of the zone is determined by whether it is found in the marshy or drier regions. While the marshy zones or swamps are used for fishing and seasonal farming

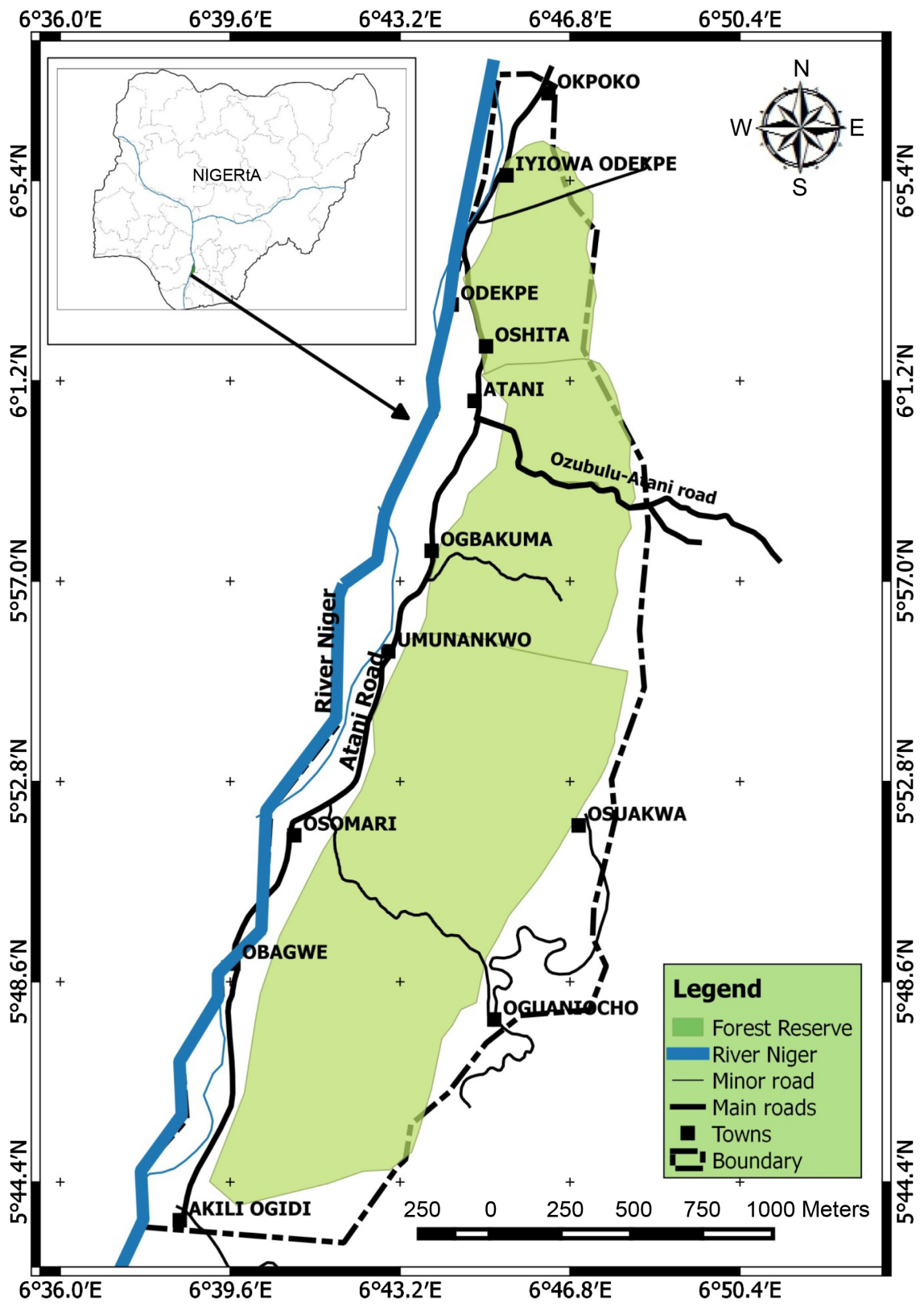

Figure 1. Map of the study area showing the reserve and the Nigerian map inset. 
activities, the dry lands are used predominantly for farming activities and for settlement purposes.

\subsection{Vegetation Inventory}

Vegetation surveys were conducted in the forest reserve (Figure 1) in order to understand its biodiversity attributes. Standard forest plots were set up randomly across the sites between December 2013 and April 2014. A total number of 4 plots, which were 1 ha $(100 \times 100 \mathrm{~m})$ each, was used to survey the sites. All the trees that measured $\geq 10 \mathrm{~cm}(\mathrm{DBH})$ were identified to species levels across the sites. Tree species identification followed the taxonomy of Nigerian plants [15].

\subsection{Data Analysis}

Importance values were used to characterize the sites and summarize the abundance of each site as follows:

Species importance values (SIV) $=$ Relative density + Relative frequency + Relative dominance [16]. Where:

$$
\begin{gathered}
\text { Relative Density }=100 \times \frac{\text { Number of stems of a species }}{\text { Total number of stems }} \\
\text { Relative frequency }=100 \times \frac{\text { Frequency of a species }}{\text { Sum of all species }} \\
\text { Relative dominance }=100 \times \frac{\text { Total basal area of a species }}{\text { Total basal area of all species }}
\end{gathered}
$$

The diversity of the ecosystem was calculated [17] as follows:

Shannon-Wiener index:

$$
H^{\prime}=-\sum_{i=1}^{s} p i \ln p i
$$

where $H^{\prime}$ is the Shannon-Weiner index, $s$ is the total number of species, $p i$ is the proportion of individuals in the $i$ th species, and $\ln$ is the natural logarithm.

Species richness was calculated as the number of species in occurrence.

\section{Results and Discussion}

\subsection{Composition, Diversity and Abundance of the Sites}

The sites varied in their species composition, frequency and abundance. A total number of eleven species were found in the reserve. Mean diversity for the reserve was 0.85 . The most abundant species in the reserve were: Elaeis guineensis, Gmelina arborea and Tectona grandis, with SIV values of 182.03, 24.97 and 16.36, respectively (Table 1). Most of the species in the reserve were lost through clear felling of trees and subsequent replacement with exotic trees. This idea (of replacing indigenous species with exotic ones) have been an age long tradition across the reserves in the country mainly because, they grow faster and are able to yield much logs of wood over the years [18]. This underscores why species 
Table 1. List of species in occurrence and their respective importance values.

\begin{tabular}{cccccc}
\hline Species & Family & $\begin{array}{c}\text { Relative } \\
\text { density }\end{array}$ & $\begin{array}{c}\text { Relative } \\
\text { frequency }\end{array}$ & $\begin{array}{c}\text { Relative } \\
\text { dominance }\end{array}$ & $\begin{array}{c}\text { Species } \\
\text { importance } \\
\text { value }\end{array}$ \\
\hline $\begin{array}{c}\text { Anthocleista djalonensis } \\
\text { Brachystegia eurycoma }\end{array}$ & Gentianaceae & 0.478469 & 11.11111 & 0.0060222 & 11.5956 \\
Ceiba pentandra & Malvaceae & 0.478469 & 11.11111 & 0.0074459 & 11.59703 \\
Elaeis guineensis & Arecaceae & 74.64115 & 11.11111 & 96.277904 & 182.0302 \\
Eucalyptus spp & Myrtaceae & 0.239234 & 5.555556 & 0.003912 & 5.798702 \\
Ficus capensis & Moraceae & 0.717703 & 11.11111 & 0.0123637 & 11.84118 \\
Gmelina aborea & Lamiaceae & 11.96172 & 11.11111 & 1.9141603 & 24.98699 \\
Mangifera indica & Meliaceae & 0.717703 & 11.11111 & 0.0180519 & 11.84687 \\
Pentaclethra macrophylla & Leguminosae & 1.196172 & 11.11111 & 0.0415558 & 12.34884 \\
Strombosia pusulata & Olacaceae & 0.239234 & 5.555556 & 0.0005916 & 5.795382 \\
Tectona grandis & Lamiaceae & 9.090909 & 5.555556 & 1.716055 & 16.36252 \\
\hline
\end{tabular}

like Gmelina arborea, Tectona grandis and Eucalyptus spp are common features of the reserve's biodiversity (Table 1). Since most reserves in Nigeria adopt such pattern of forest management, the extent to which biodiversity could be conserved in such landscapes seems minimal. This is particularly a major concern for conservation because, such landscapes are rarely characterized by other species that are not exotic. Other forest landscapes (outside the reserves) cannot be relied on either to host much biodiversity, because they are mainly owned by communities and families that depend on it for livelihood and sustenance, and care very little about its conservation [19] [20].

Even though the reserves have the potential to produce wood (timber), they however stand the chance of being affected easily by diseases and pests. This is mainly because, since the landscapes are composed of only few species, their ability to withstand disease and pest infestations are much reduced, unlike other forest landscapes with higher species diversity. Since the forest reserve are equally characterised by the presence of other (few indigenous) tree species, efforts should be targeted at promoting the coexistence of both indigenous and (planted) exotic species; as such could help in promoting the resilience of such landscapes as well as their functional traits.

\subsection{Stand Structure}

The plots were generally characterized by a higher concentration or proportion of trees in the lower structural class $(10-40 \mathrm{~cm}$; Figure 2); thus, showing its extent of degradation. The highest number of tree stems were seen in the upper stratum of the forest structure (Figure 2), with lesser number of trees in the immediate next forest structural class. This showed the trees were not generally allowed to attain maturity before they are being logged and that little or nothing is left to reach a climax population. Much of the relative density of species found across the forest landscapes were concentrated on Elaeis guineensis and then on 


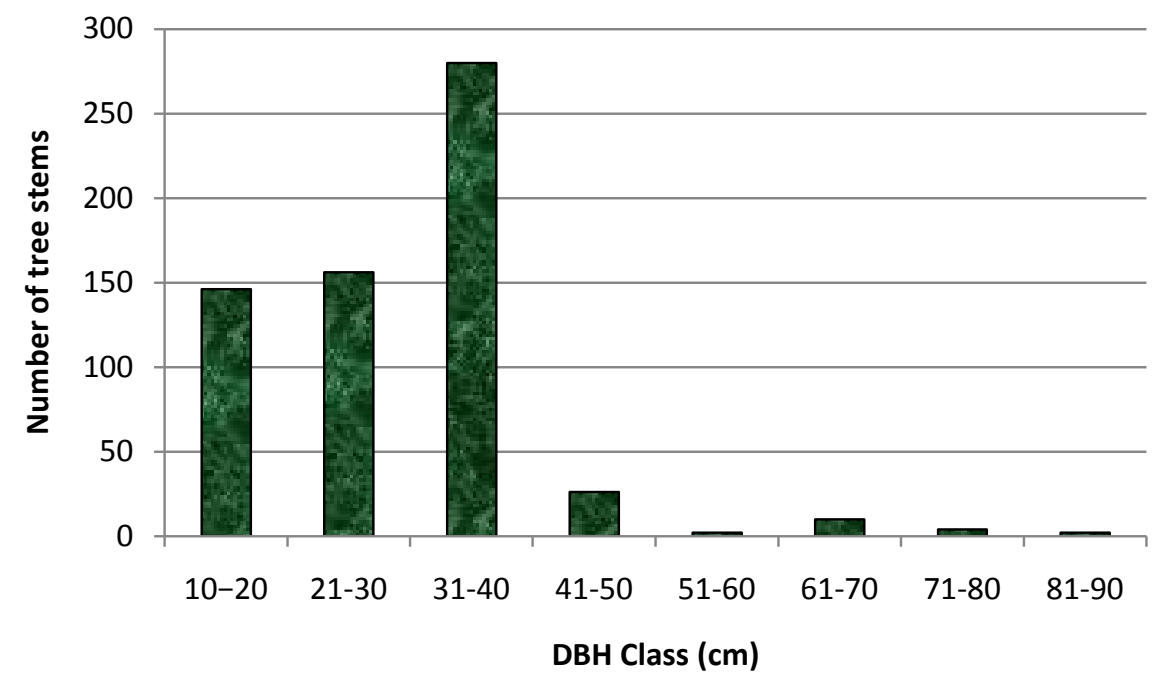

Figure 2. Frequency of occurrence of tree stems according to their DBH categories.

Gmelina arborea; as both had the highest relative densities (74.64 and 11.96, respectively; Table 1 ).

Understanding the stand structure of forest ecosystems are vital measures or steps towards providing guidelines for the effective management of forest ecosystems. However, since this is not being considered in most occasions, there is usually a wide gap between the number of tree stems in the lower and higher stratum. Since much of the trees are normally logged before they reach their emergent phase, the ability of such landscapes to have sufficient seed bank and provide other vital ecosystem functions become much reduced. This affects both the biodiversity potentials of such landscapes and their conservation prospects as well. On the other hand, the abundance and dominance of Elaeis guineensis across the landscape reduces its capacity to be characterized by indigenous species and in turn, their resilience.

The use of forest reserves for other purposes apart from the original aim for establishing them have become common features across most reserves in Nigeria. In most occasions, it has suffered from degradation and loss due to encroachments from farming activities, illegal logging, firewood gathering, settlement expansion and road constructions [11] [18] [21] [22]. Such attitudes not only reduce the capacity and ability of established reserves to provide biodiversity and its associated benefits, but furthermore, reduce the resilience of such landscapes and their ability to cope with environmental changes. Conversely, with other species such as Gmelina arborea equally dominating the landscape, the chances of utilizing the reserve to preserve or conserve the biodiversity of the (local) ecosystem appears low. Since such exotic species grow fast and become more easily established than indigenous species, they stand the chance of equally replacing or altering the colonization history of such landscapes.

\subsection{Prospects for Biodiversity and Carbon Storage}

The reserve were generally degraded (Figure 2 ) and lacked adequate management. 
Such poor management were responsible for the poor structure of the landscape and in effect, its low biomass. Since the biomass of the landscape was much reduced, its ability to store carbon would be reduced as well. Even though forest reserves were originally established to protect timber and forest resources [18], their prospects for carbon storage should equally be considered and harnessed as well. This may require reappraising the policies guiding forest reservation and conservation, and exploring the possibilities of adjusting the guidelines to accommodate carbon sequestration as well. Such steps will help to ensure that adequate attention is not only given to such issues, but proactive steps towards achieving them also enhanced.

Though forest reserves were originally gazetted across Nigeria to facilitate biodiversity conservation, it is far from being achieved as most reserves (as in this study) are degraded and characterized by low species richness. Relying on other forest landscapes (outside the reserve) to achieve biodiversity conservation may not equally be a better option since their owners easily permit logging and degradation of the forests for economic reasons [20]. Hence, though the reserve was much degraded, it still possesses the potential to facilitate a guaranteed habitat for biodiversity if managed well. This is mostly because, it is characterized by a large expanse of land; being gazetted in the 1920's when community lands were much available and the pressures associated with population growth and density were still low in the region. Such vast land is owned and controlled by the government and its continual existence (and availability for targeted biodiversity conservation) is more assured than the landscapes under private and community ownership. As the economic value or rent that accrues from (forest) lands in the region and across most tropical forest landscapes continues to rise, facilitating biodiversity conservation and carbon storage is likely to become less feasible in non-government (owned) controlled forest landscapes. Since many forest reserves are characterized by vast extents of land, the government should ensure that they are fully utilized for its sole purpose of conserving biodiversity and in effect, contribute maximally to adequate carbon sequestration across the region.

\section{Conclusion}

Even though forest reserves have the potential to host a wide range of biodiversity across tropical forest landscapes, this is not mostly achieved. This study showed that though the reserve had such potentials, it was characterized by low diversity and a low relative density that concentrated only on two species. Degradation and its consequent poor stand structure were seen to reduce the capacity to which the landscape could reach stable/climax population and suitably provide its functions and services. Utilizing the reserve's large expanse of land effectively will help to facilitate biodiversity conservation and also provide a suitable landscape that could enhance more carbon storage capacities for the region. 


\section{References}

[1] FAO (2005) Global Forest Resources Assessment. United Nations Food and Agriculture Organization, Rome.

[2] Butler, R.A. and Laurance, W.F. (2008) New Strategies for Conserving Tropical Forests. Trends in Ecology and Evolution, 23, 469-472.

https://doi.org/10.1016/j.tree.2008.05.006

[3] Pimm, S.L. and Raven, P.R. (2000) Biodiversity: Extinction by Numbers. Nature, 403, 843-845. https://doi.org/10.1038/35002708

[4] Bradshaw, C.J.A., Sodhi, N.S. and Brook, B.W. (2009) Tropical Turmoil-A Biodiversity Tragedy in Progress. Front. Ecol. Environ, 7, 79-87.

https://doi.org/10.1890/070193

[5] Laurance, W.F., Useche, D.C., Rendeiro, J., Kalka, M., Bradshaw, C.J.A., Sloan, S.P., Laurance, S.G., Campbell, M., et al. (2012) Averting Biodiversity Collapse in Tropical Forest Protected Areas. Nature, 489, 290-294.

https://doi.org/10.1038/nature11318

[6] IUCN (1994) Guidelines for Protected Area Management Categories. IUCN, Gland and Cambridge.

[7] Ezebilo, E.E. (2013) Nature Conservation in Cross River National Park, South-East Nigeria: Promoting Collaboration between Local People and Conservation Authorities. International Journal of Biodiversity Science, Ecosystem Services and Management, 9, 215-224.

[8] Gardner, T.A., Barlow, J., Chazdon, R., Ewers, R.M., Harvey, C.A., Peres, C.A. and Sodhi, N.S. (2009) Prospects for Tropical Forest Biodiversity in a Human-Modified World. Ecology Letters, 12, 1-21. https://doi.org/10.1111/j.1461-0248.2009.01294.x

[9] World Bank (1992) Federal Republic of Nigeria: Forestry Sector Review. Confidential Report No 10744-UNI, 96 p.

[10] FRA (2010) Global Forest Resources Assessment 2010 Country Report Nigeria. FRA 2010/151. Food and Agriculture Organization of the United Nations, Rome.

[11] FAO (2003) Experience of Implementing National Forest Programmes in Nigeria. Sustainable Forest Management Programme in African ACP Countries. EC-FAO Partnership Programme (2000-2003).

[12] Areola, O. (1982) Soils. In: Barbour, K.M., Oguntoyinbo, J.S., Onyemelukwe, J.O.C. and Nwafor, J.C., Eds., Nigeria in Maps, Hodder and Stoughton, London, 22-23.

[13] Akintola, F. (1982) Geology and Geomorphology. In: Barbour, K.M., Oguntoyinbo, J.S., Onyemelukwe, J.O.C. and Nwafor, J.C., Eds., Nigeria in Maps, Hodder and Stoughton, London, 12-13.

[14] Keay, R.W. (1959) An outline of the Nigerian Vegetation. Federal Department of Forest Research, Federal Ministry of Information, Lagos.

[15] Keay, R.W.J. (1989) Trees of Nigeria. Clarendon Press, Oxford, UK.

[16] Cottam, G. and Curtis, J.T. (1956) The Use of Distance Measurements in Phytosociological Sampling. Ecology, 37, 451-460. https://doi.org/10.2307/1930167

[17] Kent, M. and Coker, P. (1992) Vegetation Description Analysis. Wiley, Chichester.

[18] Usman, B.A. and Adefalu, L.L. (2010) Nigerian Forestry, Wildlife and Protected Areas: Status Report. Biodiversity, 11, 44-52.

[19] Igu, N.I. and Marchant, R. (2016) Aboveground Carbon Storage in a Freshwater Swamp Forest Ecosystem in the Niger Delta. Carbon Management, 7, 137-148.

[20] Igu, N.I. and Marchant, R. (2017) Potential and Determinants of Carbon Storage of Freshwater Swamp Forests in the Niger Delta. Open Journal of Ecology, 7, 199-210. 
https://doi.org/10.4236/oje.2017.73015

[21] USAID (2008) Nigeria Biodiversity and Tropical Forestry Assessment. Maximizing Agricultural Revenue in Key Enterprises for Targeted Sites (Markets). United States Agency for International Development Publication. Chemonics International Inc.

[22] Meduna, A.J., Ogunjinmi, A.A. and Onadeko, S.A. (2009) Biodiversity Conservation Problems and Their Implications on Ecotourism in Kainji Lake National Park, Nigeria. Journal of Sustainable Development in Africa, 10, 59-73.

Submit or recommend next manuscript to SCIRP and we will provide best service for you:

Accepting pre-submission inquiries through Email, Facebook, LinkedIn, Twitter, etc. A wide selection of journals (inclusive of 9 subjects, more than 200 journals)

Providing 24-hour high-quality service

User-friendly online submission system

Fair and swift peer-review system

Efficient typesetting and proofreading procedure

Display of the result of downloads and visits, as well as the number of cited articles

Maximum dissemination of your research work

Submit your manuscript at: http://papersubmission.scirp.org/

Or contact jep@scirp.org 